\title{
NASKAH SURAT AKTA JULL BELI TANAH SAWAH KEPEMILIKAN TANAH PADA AWAL ABAD KE-20
}

\section{TITLE DEED TRANSACTIONS OF RICE FIELD: LAND OWNERSHIP IN THE EARLY OF $20^{T H}$ CENTURY}

\author{
Nurhata
}

STKIP Pangeran Dharma Kusuma Segeran Juntinyuat Indramayu Jl. KH. Hasyim Asyari, Ds. Segeran Kidul, Kec. Juntinyuat, Kab. Indramayu e-mail: muhammadnurhata@gmail.com

Naskah Diterima: 16 September $2018 \quad$ Naskah Direvisi:25 Desember $2018 \quad$ Naskah Disetujui: 27 Maret 2019

DOI: 10.30959/patanjala.v11i1.441

\begin{abstract}
Abstrak
Penelitian ini akan menguraikan salah satu naskah (manuscript) akta jual beli tanah sawah yang ditemukan di Desa Srengseng, Indramayu. Akta yang menjadi objek penelitian ini adalah yang paling tua, ditulis dengan menggunakan aksara Jawa, bahasa Jawa. Dilihat dari kandungan isinya, surat tersebut tergolong surat penting. Tujuan penelitian ini adalah untuk melacak kandungan isi surat sebagai representasi zamannya. Metode yang digunakan adalah filologi. Beberapa pihak yang tercatat dalam surat adalah nama penjual dan pembeli, juru tulis, kuwu, dan saksi-saksi, termasuk mengenai luas tanah dan lokasinya juga dijelaskan, sebagaimana surat jual beli tanah pada umumnya, baik yang dikenal pada awal abad ke-20 atau pada saat ini. Adapun kandungan isinya berupa keterangan bahwa Bapak Salinah membeli sebidang tanah sawah kepada seorang mantan kuwu, Bapak Kadam, pada tanggal 10 November 1915, seharga 32 rupiah. Surat tersebut menegaskan bukti sah kepemilikan atas sebidang tanah sawah pada awal abad ke-20.
\end{abstract}

Kata kunci: akta jual beli, sawah, Indramayu.

\section{Abstract}

This study describes one of the manuscripts about the deed of sale and purchase of rice field that had been found in Srengseng Village, Indramayu. The deed that is finally used as the data is the oldest one. The chosen manuscript is written in Javanese scripts. Referring to its content, the letter is classified as an important letter. The purpose of this research is to investigate the content of the old deed. Furthermore, the method which is applied is philology. As a research of this research is there are some parties written in the old deed, namely seller's and buyer's name, a clerk's name, village chief, and a couple of witnesses or more. Beside that, some modern deed elements such as the size of the area and the location, as commonly known nowadays, also exist. Regarding the story of the content, the manuscripts tells about Mr. Salinah who purchased a rice field from and ex village chief, named Mr. Kadam, at November 10th, 1915, for 32 Indonesian rupiah. Finally this deed manuscript can be regarded as an ownership legitimisation of a rice field in the early of 20th century.

Keywords: Deed of Sale and Purchase, rice field, Indramayu.

\section{A. PENDAHULUAN}

Kabar

keberadaan

naskah (manuscript) surat jual beli tanah sawah atau akta tanah, semula disampaikan oleh teman lama saya, Rahmatullah. Tidak lama kemudian saya mendatangi tempat penyimpanan surat itu. Kami bergegas ke sana, menuju lokasi penyimpanan. Sesampainya di tujuan, semua surat saya baca satu per satu. Semuanya dalam kondisi lapuk, kusam, dan berdebu, tetapi masih jelas terbaca. Isinya tidak hanya berupa akta jual beli tanah sawah, tetapi juga akta jual beli tanah pekarangan, surat 
gadai, dan surat pajak. Sebagian besar surat ditulis dengan aksara Jawa, hanya beberapa saja yang ditulis dengan aksara latin.

Semula saya menduga, sebelum menyaksikan langsung, catatan-catatan lama itu berupa naskah kuna yang berisi cerita-cerita babad, teks-teks keagamaan, primbon, dan lain-lain (meskipun suratsurat itu juga dapat disebut dengan naskah kuna). Temuan sebelumnya, sejak tahun 2013 sampai tahun 2016, ${ }^{1}$ Indramayu (terutama di bagian barat) memang menjadi kantong penyimpanan naskah dengan aneka macam genre. Ternyata, semuanya berisi dokumen pribadi keluarga yang dibuat pada era kolonial Belanda pada awal abad ke-20.

Dokumen-dokumen itu adalah cerminan sejarah dan budaya suatu kelompok masyarakat, yang tentunya berguna bagi kajian agraria pada umumnya atau sejarah kepemilikan tanah pada khususnya. Di Indonesia, kajian penelitian agraria dimulai sejak Raffles, diuraikan dalam dua jilid History of Java, lalu dimatangkan oleh bawahannya John Crawfurd dalam History of Indian Archipelago (1820) sebanyak 3 jilid. Penelitiannya menguraikan tata cara bercocok tanam, tentang kehidupan agraria, serta peran penting sektor agraria bagi peningkatan pendapatan publik dan perdagangan internasional (Farid, 2017: 1$2)$.

Berkenaan dengan kepemilikan tanah khususnya di Jawa Barat, Boomgard, secara tradisional, membaginya menjadi dua yaitu tanah perorangan dan tanah komunal. Tanah komunal muncul ketika sekelompok orang membuka lahan hutan, yang kelak digunakan secara bersamasama atau digunakan secara bergilir. Mereka hanya memiliki hak pakai.

\footnotetext{
${ }^{1}$ Dalam "Kearifan Lokal dalam Naskah-naskah Pesisir Indramayu: Pengembangan Budaya Pesisir melalui Knowledge Management System" (Christomy, T dan Nurhata 2013) dan Katalog Naskah Indramayu (Christomy, T dan Nurhata, 2016).
}

Sementara itu, tanah perorangan diperoleh dengan cara membuka lahan sendiri atau membabat hutan untuk kepentingan keluarga sendiri (dalam Suhendar, 1995: 9).

Selain itu, ada yang disebut dengan tanah partikelir, yang sebetulnya tidak jauh berbeda dari tanah milik perorangan. Kemunculannya ketika memasuki era kolonial Belanda. Di Indramayu, terutama di bagian barat, tanah partikelir menjadi salah satu faktor penyebab atas meletupnya pemberontakan pada awal abad ke-19 dan awal abad ke-20. Kisah pemberontakannya digambarkan begitu dramatis dalam naskah Babad Darmayu (koleksi Dalang Ahmadi) dan naskah Sedjarah Kuntjit. (koleksi Ki Masta).

Persoalan kepemilikan tanah di Hindia Belanda tidak dapat dilepaskan dari Undang-undang Agraria (Agrarische Wet), yang dibuat pada tahun 1870. Undangundang tersebut bertujuan memberikan ruang kepada swasta (pihak asing) supaya bisa menyewa tanah. Pada saat yang bersamaan, undang-undang itu juga memiliki tujuan melindungi tanah milik penduduk pribumi. Namun demikian, tanah-tanah yang tidak memiliki surat resmi, baik yang dimiliki secara komunal maupun perorangan, akan dianggap sebagai tanah milik negara (domein verklaring). Hal tersebut telah mengakibatkan sejumlah penduduk kehilangan tanah, diambil alih oleh pemerintah, dan menjadi tanah pemerintah Hindia Belanda (Suhendar, 1995: 12).

Undang-undang Agraria berdampak serius bagi struktur sosial yang ada. Selama tiga per empat abad undangundang itu telah menciptakan hierarki dalam penguasaan tanah, yaitu tuan tanah (pemilik tanah luas), pemilik tanah sedang, pemilik tanah kecil, dan petani tanpa tanah. Tuan tanah ada yang mengerjakan tanahnya sendiri, menyewakannya kepada orang lain, atau membiarkannya kosong. Pemilik sawah sedang, sebagian ada yang menggarapnya sendiri atau menyewakannya kepada orang lain. 
Sementara pemilik sawah kecil, biasanya menggarap tanahnya sendiri sembari mengerjakan tanah milik orang lain (maro). Sedangkan yang tidak memiliki tanah, akan menjadi buruh tani atau sembari maro. Di samping itu, ada pula yang hanya sebagai buruh tani totok (Hardjosudarmo, 1967, dalam Suhendar, 1995: 20-21).

Para tuan tanah tentu saja mampu membeli tanah dalam jumlah besar kepada petani sedang atau petani kecil. Para petani kecil yang tidak mampu mempertahankan tanahnya maka akan dijual kepada tuan tanah, terutama karena masalah himpitan ekonomi. Pada awalnya menggadaikan tanahnya ke petani besar, lambat laun menjualnya, seperti yang terjadi di Cirebon. $^{2}$ Oleh karena mereka tidak memiliki tanah akhirnya hanya menjadi buruh tani atau sembari maro 'bagi hasil'. Hal ini telah menciptakan garis demarkasi antara tuan tanah dan buruh tani.

Faktor lain yang memicu ketimpangan kepemilikan lahan yaitu karena adanya sistem waris -sebidang tanah dipecah lalu dibagi kepada keluarga yang memiliki hak waris sehingga luas lahan yang dimiliki oleh generasi berikutnya semakin sempit. Selain itu juga adanya lahan guntai, yakni lahan yang pemiliknya berasal dari luar desa atau absente (Winarso, 2012: 143).

Kondisi semacam itu umum terjadi di Jawa Barat. Pada tahun 1905, dalam Mindere Welvaart Onderzoek, sebanyak

\footnotetext{
${ }^{2}$ Wakil Inspektur Urusan Agraria (1918-1925), J.W. Meijer Ranneft, dalam arsip pribadinya memberikan ulasan sewaktu melakukan perjalanan dinas ke wilayah utara Cirebon pada tahun 1919. Menurutnya, peningkatan jumlah penduduk dan masalah hutang telah mengakibatkan perekonomian warga semakin buruk. Tanah yang digadaikan tidak sanggup melunasinya sehingga tidak sedikit yang diambil oleh pihak pemberi pinjaman. Masalah itu, menurutnya dapat diatasi dengan mengembalikan tanah kepada penduduk, mendaftar ulang, mencatat semua hutang, serta membentuk aturan pelunasannya (Anrooij, 2014: 44).
}

$51 \%$ petani di Jawa Barat adalah keluarga penggarap pertanian milik orang lain dengan cara bagi hasil (tunakisma). Dari jumlah tersebut, $67 \%$ di antaranya memiliki lahan kurang dari satu bau $(0,7$ hektar), tetapi sebanyak 7\% lainnya justru berhasil menghimpun tanah dalam jumlah besar hingga lebih dari 6 bau (4.2 hektar). Bahkan di wilayah Priangan pada tahun 1905, tanah seluas lebih dari 30 bau hanya dikuasai oleh 559 keluarga, dan pada tahun 1925, yang memiliki tanah seluas itu meningkat menjadi 1226 keluarga (Mears, dalam Suhendar 1995: vi).

Senada dengan penjelasan Mumuh (2011: 394-395), bahwa lahan di pedesaan Priangan yang sebagian besar berupa persawahan memang dimiliki secara pribadi. Sebanyak 101 desa dari 105 desa (96\%), sebagian besar wilayahnya adalah tanah sawah, yang mana itu menjadi hak milik perorangan. Sebagai tanah milik perorangan maka pemiliknya dapat menggarapnya sendiri, memberikan ke anak keturunannya, atau menjualnya kepada pihak lain.

Di Indramayu bagian barat, selama setengah abad (1885-1935), karena tanahnya sangat subur dan produktivitas padi sangat tinggi, pemilik sawah enggan melepaskan tanahnya. Namun keadaan justru terbalik, kemiskinan merajalela, karena masyarakat terlilit hutang kepada para tengkulak (sejak tahun 1880an). Penyebabnya gaya hidup masyarakat sangat konsumtif. Upaya pemerintah kolonial mengalami kegagalan dalam menyelesaikan masalah itu. Pemerintah tidak mampu membeli padi dengan harga normal kepada petani pada saat panen melimpah dan harganya sedang anjlok. Ketika panen berhasil, petani lebih memilih menjualnya kepada tengkulak, meskipun dengan harga murah. Semuanya tidak dalam kendali pemerintah kolonial sehingga kondisi masyarakat dalam keadaan memprihatinkan (Fernando, 2010).

Keadaan itu berbeda dari Indramayu bagian timur, khususnya wilayah 
Krangkeng, yang kerap dilanda kekeringan bahkan hingga saat ini. Itu sebabnya para pemilik tanah tidak bersungguh-sungguh mempertahankan tanahnya, terburu-buru menjualnya ke orang lain. Tidak mengherankan bila pada awal abad k-20, ada beberapa orang yang menguasai tanah dalam jumlah besar, seperti Bapak Salinah, dan ada banyak orang yang tidak memiliki lahan pertanian atau hanya sedikit saja yang dimiliki.

Persoalan kepemilikan tanah diperlukan suatu legalitas dari pemerintah, berupa akta, baik itu tanah yang diperoleh dari hasil membabat suatu hutan atau tanah yang diperoleh dengan cara membeli, termasuk tanah warisan. Akta itu menjadi bukti sah kepemilikan sebidang tanah sawah, tanah pekarangan, atau tanah yang di atasnya terdapat suatu bangunan. Surat itu pula yang akan menjamin status kepemilikan tanah. Tanpa bukti kepemilikan seperti akta atau sertifikat, status kepemilikannya berpotensi dipersoalkan oleh orang lain atau dapat mengakibatkan sengketa. ${ }^{3}$

${ }^{3}$ Persoalan sengketa sudah ada sejak era Jawa Kuna. Dalam Prasasti Panggumulan II berangka tahun $903 \mathrm{M}$ menyatakan Pu Palaka beserta istri dan tiga anaknya (Palaku, $\mathrm{Pu}$ Gowinda, dan Dyah Wangi Tamuy) menebus sebidang kebun yang terletak di Desa Sidhayoga dan sebidang sawah di Panilwan senilai 3 kati perak. Si penggadai bernama Dapunta Prabu dan Dapunta Kaca, pejabat Desa Panggumulan (Suhadi, 1996/1997: 30). Dalam prasasti Bendosari dan Manah I Manuk juga dikisahkan masalah sengketa tanah antara Aki Santana, Mapanji Sarana, Ki karna, Mapanji manakara, Ki Ajaran Reka, Ki Siran, dan Ki Jumput (dari desa Manah I Manuk) berhadapan dengan Mapanji Anawung Harsa dan kawan-kawan dari Desa Sima Tiga. Masalahnya, tanah seluas 67 lirih yang tersebar di berbagai desa adalah milik Aki Santana dan kawan-kawan, diperoleh turun-temurun dari bapak, kaki, buyut, pitung, anggas, muning, dan krepek (7 turunan nenek moyang ke atas), yaitu sejak tahun 919 Saka (997 M). Warga desa Sima Tiga kemudian menuntutnya sebagai tanah milik karena tanah tersebut pada mulanya digadaikan oleh nenek moyangnya dengan nilai
Memasuki era kemerdekaan, negara mengatur sedemikian rupa tentang aturan jual beli tanah. Pembuatan akta yang tidak sesuai dengan ketentuan maka pihak yang berwenang mengurus tanah (PPAT) akan diberhentikan dengan tidak hormat. Di samping itu, kekuatan hukumnya dapat dianggap sebagai akta di bawah tangan, yang mana sangat berisiko bagi si pemilik, diklaim oleh pihak lain (Purwanti, 2016). Format akta yang dibuat PPAT (Pejabat Pembuat Akta Tanah) sudah disediakan, diatur dalam pasal 1 Peraturan Pejabat Pembuatan Akta Tanah Jo; pasal 96 ayat (2) Peraturan Menteri Negara Agraria/Kepala BPN RI No. 3 Tahun 1997 tentang Ketentuan Pelaksanaan PP No. 24 Tahun 1997, tentang Pendaftaran Tanah. Tata cara atau tahapannya harus diikuti, sedikit pun tidak boleh ada perubahan. Jika keluar dari aturan pembuatan akta otentik maka berakibat hukum, pembuktian akta tidak memiliki kekuatan hukum (Purwanti, 2016: 131).

Kajian penelitian tentang naskah akta surat jual beli tanah pada era kolonial Belanda yang menggunakan metode filologi setakat ini hanya dapat dilihat dalam "Jejak Penjajahan pada Naskah Sunda: Studi Kasus pada Surat Tanah" (Ruhaliah, 2010). Struktur isi surat dalam penelitian ini tidak jauh berbeda dari akta surat jual beli tanah yang ditemukan di Indramayu. Perbedaaan yang paling mencolok yaitu dari segi bahasa, yang sudah disesuaikan. Surat dari Indramayu berbahasa Jawa sedangkan surat dari Priangan berbahasa Sunda.

Penelitian ini akan menguraikan naskah akta surat jual beli tanah sawah yang dibuat pada tahun 1915. Surat tersebut digulung bersama puluhan surat lain, tersimpan dalam tabung kaleng berkarat. Pilihan atas surat tersebut karena alasan filologis. Usia surat lebih tua bila dibandingkan dengan surat-surat lain yang tersimpan dalam tempat yang sama.

kalitengah taker perak (dua setengah takar perak) ketika Jawa belum mengenal pisis, yaitu mata uang logam (Zoetmulder, 1983: 1371). 


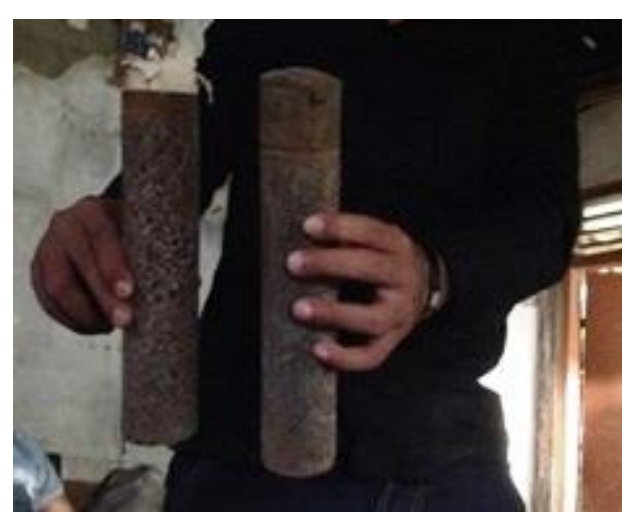

Gambar 1. Tabung penyimpanan surat Sumber: Nurhata, 2017.

Ada dua pertanyaan yang ingin saya kemukakan dalam artikel ini, (1) bagaimana surat-surat tanah sampai ke tangan pemilik sekarang, dan (2) bagaimana kandungan isinya. Pertanyaan pertama, saya akan melakukan wawancara kepada pemilik surat. Sementara itu, untuk menguraikan jawaban yang kedua, suatu teks terlebih dahulu dideskripsikan, dialihaksarakan, lalu diterjemahkan, selanjutnya dianalisis satu per satu tentang unsur-unsur pokok yang disebutkan di dalamnya.

\section{B. METODE PENELITIAN}

Dalam ilmu filologi, surat jual beli tanah sawah dapat disebut dengan naskah (manuscript). Sebagai naskah kuna maka cara untuk mengkajinya pun sama dengan naskah-naskah lain pada umumnya. Biasanya, masyarakat Indramayu terutama yang berusia sepuh, untuk menyebut naskah adalah "lontar", meskipun media tulisnya bukan lontar.

Terdapat dua cabang dari filologi, yaitu kodikologi dan tekstologi. Kodikologi berasal dari bahasa Latin codex, jika diterjemahkan ke dalam bahasa Indonesia berarti naskah (fisik). Ranah kodikologi meliputi sejarah atau asal-usul naskah, koleksi naskah, tempat penyimpanan naskah, penyusunan katalogus naskah, perdagangan naskah, dan pemanfaatan naskah (Mulyadi, 1994: 1-3; Karsono, 2008: 79; Baried, 1985: 55).
Adapun tekstologi (text dan logos) mengkaji persoalan seputar teks, seperti sejarah teks, relasi antara satu teks dan teks lain, dan persebaran suatu teks, termasuk penurunan, penafsiran atau pemahaman suatu teks (Karsono, 2008: 79; Baried, 1985: 57).

Untuk menghadapi suatu naskah, bergantung pada kondisi naskah yang dihadapi karena setiap naskah memiliki keunikan, kekhasan, atau permasalahannya sendiri. Ada tiga metode penyuntingan naskah, yakni metode stemma, metode gabungan, dan metode landasan (Robson (1994: 21-27). Karsono (2008: 104) menyebutnya empat metode, yaitu intuitif, landasan, gabungan, dan stemma. Sementara Baried, dkk (1985: 67-69) menambahkan satu metode lagi, yaitu metode intuitif, metode stemma (objektif), metode gabungan, metode landasan, dan metode naskah tunggal.

Metode yang digunakan untuk mengungkap informasi dari dalam naskah akta surat jual beli tanah sawah yaitu metode landasan. Metode ini bertolak dari alasan bahwa naskah yang dihadapi memiliki kualitas lebih unggul dari yang lain (dari satu versi atau satu varian), baik dari sudut bahasa, sastra, maupun sejarah (Baried, dkk, 1985: 68-69; Karsono, 2008: 105). Dari segi usia, naskah tersebut paling tua di antara naskah-naskah lain (dalam satu koleksi). Di samping itu, tingkat keterbacaannya pun sangat jelas dan lengkap. Namun, sebelum naskah dianalisis dengan menggunakan metode filologi, terlebih dahulu akan dikaji secara kodikologi, darimana asal-usul naskah tersebut.

Naskah akta surat jual beli sawah adalah naskah tunggal. Ini tidak mengherankan karena kaitannya dengan kepentingan pribadi seseorang atau keluarga, bukan suatu teks yang dapat dikonsumsi oleh publik seperti naskah babad pada umumnya. Meskipun begitu, pada analisisnya, akan mengacu pada naskah atau surat-surat lain sejenis, yang tersimpan dalam satu koleksi. 


\section{HASIL DAN BAHASAN \\ 1. Arsip Desa di Indramayu}

Dalam ilmu sejarah, naskah akta surat jual beli tanah dapat digolongkan sebagai arsip. Istilah arsip dalam Kamus Oxford (2008: 53) berarti dokumen sejarah atau rekaman yang memuat informasi tentang suatu tempat, institusi, atau kelompok manusia. Dalam KBBI (2008: 87), yang disebut dengan arsip adalah dokumen masa lampau, baik tertulis (surat, akta, dan sebagainya), lisan (pidato, ceramah, dan sebagainya), maupun bergambar (foto, film, dan sebagainya), yang disimpan dengan menggunakan media tulis (kertas) dan elektronik (pita kaset, pita video, disket komputer, dan sebagainya). Biasanya, suatu dokumen dikeluarkan oleh instansi resmi, disimpan, dan dirawat di tempat khusus sebagai sumber referensi.

Berdasarkan jenisnya arsip terbagi menjadi dua yaitu arsip statis (tidak lagi digunakan) dan arsip dinamis (masih digunakan). Terutama arsip statis yang dibuat pada era kolonial, tidak sedikit yang rusak dan jumlahnya terus berkurang, baik disebabkan oleh faktor alam maupun karena kesengajaan manusia. Merujuk pada definisi arsip di atas dan pembagiannya, maka surat jual beli sawah dapat disebut sebagai arsip statis, yang memiliki kegunaan sebagai sumber referensi, terutama yang bertalian dengan sejarah agraria.

Di Indonesia, lembaga yang banyak menyimpan arsip statis adalah kantor Arsip Nasional Republik Indonesia (ANRI). Masalah kearsipan ini diatur dalam Undang-Undang Nomor 43 Tahun 2009, Keputusan Presiden Nomor 103 Tahun 2001, Keputusan Presiden Republik Indonesia Nomor 27/M Tahun 2010, dan Peraturan Kepala Arsip Nasional Republik Indonesia Nomor 3 Tahun $2006 .{ }^{4}$

4 Undang-Undang Nomor 43 Tahun 2009 tentang Kearsipan (Lembaran Negara Republik Indonesia Tahun 2009 Nomor 152, Tambahan Lembaran Negara Republik Indonesia Nomor 5071); Keputusan Presiden Nomor 103 Tahun
Pengarsipan di Indonesia yang dikenal dewasa ini mulai marak terutama sejak bangsa-bangsa Eropa berkuasa atas seluruh Nusantara, dari tingkat pusat sampai ke tingkat paling bawah (desadesa). Sebelumnya, pendokumentasian berbagai persoalan atau informasi yang dianggap penting masih menggunakan cara-cara tradisional, yang hanya mudah dipahami menurut masyarakat setempat.

Desa sebagai kesatuan wilayah yang memiliki sistem pemerintahan sendiri, dalam perjalanannya telah meninggalkan banyak arsip statis, dalam jumlah yang melimpah. Tinggalan desa berupa arsip statis, oleh pamong desa seringkali dianggap tidak penting terutama karena persoalan bahasa dan aksara yang tidak lagi dikenali di samping karena tidak memahami kegunaan atau manfaatnya, padahal di dalamnya terekam jelas aktivitas suatu kelompok masyarakat pada masa lalu. Priyadi (2012) dalam pengantarnya, Sejarah Lokal: Konsep, Metode, dan Tantangannya menegaskan, perihal penggalian atas sejarah nasional, yang semestinya dimulai dari sejarah lokal. Menurutnya, jika penulisan sejarah lokal dimulai dari sejarah nasional maka dapat membunuh nasionalisme lokal.

Naskah akta surat jual beli sawah sebagai arsip statis kedudukannya dapat diubah menjadi arsip dinamis. Caranya, suatu arsip statis didigitalisasi dan dikelola sedemikian rupa melalui metadata dengan aneka software, sehingga berubah menjadi

2001 tentang Kedudukan, Tugas, Fungsi, Kewenangan, Susunan Organisasi, dan Tata Kerja Lembaga Pemerintah Non Departeman sebagaimana telah enam kali diubah terakhir dengan Peraturan Presiden Nomor 64 Tahun 2005; Keputusan Presiden Republik Indonesia Nomor 27/M Tahun 2010 tentang Pengangkatan Kepala Arsip Nasional Republik Indonesia; Peraturan Kepala Arsip Nasional Republik Indonesia Nomor 03 Tahun 2006 tentang Organisasi dan Tata Kerja Arsip Nasional Republik Indonesia sebagaimana telah dua kali diubah terakhir dengan Peraturan Kepala Arsip Nasional Republik Indonesia Nomor 05 Tahun 2010. 
data. Jadi penggunaannya mengalami perubahan sesuai dengan kebutuhan penciptaanya atau tujuannya. Pada tahap ini tidak lagi disebut sebagai arsip statis atau pasif karena memiliki peran bagi kehidupan manusia (Magetsari, 2008: 1213).

Melalui arsip desa, seperti naskah akta surat jual beli tanah, kajian atas sejarah lokal tidak sepenuhnya bergantung pada penelitian terdahulu, tetapi langsung bersentuhan dengan sumber primer. Menurut Taufik Abdullah (2010), salah satu problematika sejarah lokal di Indonesia karena masih bergantung pada hasil penelitian-penelitian sebelumnya dan sumber yang dipakai pun masih sangat terbatas, sudah begitu sulit diketahui keberadaannya. $^{5}$ Paling tidak, dengan memanfaatkan arsip, persoalan penelitian sejarah lokal di Indonesia bisa sedikit terjawab. Arsip memang berbeda dari historiografi tradisional yang dalam pemahamannya membutuhkan kecermatan dan ketelitian. Jika tidak cermat maka akan tergelincir ke dalam lembah mitos, dan apa yang diuraikannya tidak berbunyi suatu kajian sejarah (kritis) melainkan legenda atau cerita babad, yang masih menganggap faktor religio-magis sebagai variabel tunggal atas suatu peristiwa tertentu.

Inventarisasi terhadap arsip-arsip yang tersebar di desa-desa, khususnya di Indramayu (lebih dari 300 desa) dapat menambah khazanah kearsipan daerah, atau dapat menambah daftar koleksi kantor arsip dan perpustakaan daerah. Krihanta menjelaskan tentang bagaimana proses pemanfaatan arsip statis yang masih tersebar atau masih menjadi koleksi masyarakat. Pertama, arsip diakuisisi untuk menambah khazanah kearsipan, baik di

\footnotetext{
${ }^{5}$ Di Indonesia, kajian atas sejarah lokal mulai bertumbuhan sejak tahun 1950. Kajiannya bercorak pada: 1. studi peristiwa tertentu, 2 . menekankan struktur, 3. studi tematis, mengambil perkembangan pada aspek dan kurun waktu tertentu, 4. studi sejarah umum mengenai perkembangan suatu daerah dari waktu ke waktu (Abdullah, 2010: 28).
}

tingkat pemerintah daerah maupun pemerintah pusat. Kedua, mengelola, menata, serta menyimpannya dengan metode tertentu untuk mempermudah pencarian. Ketiga, merawat, memelihara, atau melakukan perbaikan. Keempat, memberikan layanan untuk pengguna (Krihanta, 2008: 73-76). Di tingkat daerah, pekerjaan semacam ini sangat menantang, membutuhkan perawatan yang serius, temperatur suhu ruangan yang stabil, serta tidak dapat diperlakukan sebagaimana buku teks pada umumnya, yang semuanya membawa implikasi bagi kesiapan pegawainya.

Setakat ini arsip-arsip statis yang dibuat pada masa pemerintahan Hindia Belanda, yang berisi aktivitas sosial masyarakat Indramayu, yaitu berkenaan dengan jual beli sawah, jual beli pekarangan, pajak kepala, pajak bumi, jual beli binatang ternak, surat nikah, namanama penduduk desa (sensus penduduk), nama-nama jabatan, dan jalur sungai Cimanuk dari hulu sampai ke hilir. Alas tulis yang dipakai yaitu lontar, kertas Eropa, dan kertas bergaris. Dilihat dari penanggalan yang tertera di dalamnya, diperkirakan dibuat pada abad ke-19 sampai awal abad ke-20.

Arsip-arsip yang di dalamnya menyinggung tentang Indramayu sebagian sudah diregistrasi oleh Perpustakaan Nasional RI, Arsip Nasional RI, dan lembaga-lembaga lain terkait. Sebagian lagi, masih belum diregistrasi dan masih disimpan di rumah-rumah penduduk atau di kantor desa. Arsip statis yang masih berada di rumah-rumah penduduk, yang dibuat pada era kolonial Belanda, jumlahnya sangat besar, hanya saja sulit diketemukan, dan kondisinya pun rentan rusak. Para pemilik cenderung masa bodoh dan tidak menganggapnya sebagai sesuatu yang penting.

Contoh kasus di Indramayu, ketika kantor desa dibangun, direhab, atau dibersihkan, arsip-arsip statis yang tidak berfungsi turut hancur, musnah, atau pindah ke tangan orang-orang yang tidak 
bertanggungjawab. Orang-orang sepuh yang dahulu pernah menjadi pamong desa biasanya mengetahui di mana arsip-arsip disimpan, dan pada umumnya tidak jauh dari kantor desa. Jadi, tidak ada kata terlambat untuk menghimpun kembali, yang jika diakumulasikan jumlahnya sangat besar.

\section{Arsip Desa Srengseng}

Desa Srengseng adalah salah satu desa yang menyimpan banyak arsip statis, antara lain koleksi Mas Johan, seorang petani dari Desa Srengseng, Kecamatan Krangkeng, Kabupaten Indramayu. Jumlahnya mencapai puluhan, dan sebagian besar berupa naskah surat akta jual beli sawah. Kertas yang dipakai pada surat berharga itu didisitribusikan dari Priangan, melalui afdeling Indramayu. Dari Indramyu lalu ke Distrik Karangampel, kemudian ke Onderdistrik Krangkeng, dan terakhir ke Dusun Srengseng. Dusun Srengseng membawahi beberapa blok, yaitu Blok Glagarjuna, Blok Dangklong, Blok Silawe, dan lainlain. Mengacu pada UU tentang Benda Cagar Budaya, Bab I Pasal I, semua arsip tersebut yang usianya lebih dari 50 tahun itu termasuk benda cagar budaya, yang wajib dijaga kelestariannya. ${ }^{6}$

Titimangsa yang terdapat dalam setiap arsip menunjukkan waktu pembuatannya. Adapun waktu pembuatannya dari tahun 1915 sampai

\footnotetext{
${ }^{6}$ Benda cagar budaya adalah: (a) benda buatan manusia, bergerak atau tidak bergerak yang berupa kesatuan atau kelompok, atau bagianbagian atau sisa-sisanya, yang berumur sekurang-kurangnya 50 (lima puluh) tahun, atau mewakili masa gaya yang khas dan mewakili masa gaya sekurang-kurangnya 50 (lima puluh) tahun, serta dianggap mempunyai nilai penting bagi sejarah, ilmu pengetahuan, dan kebudayaan; (b) benda alam yang dianggap mempunyai nilai penting bagi sejarah, ilmu pengetahuan, dan kebudayaan. Situs adalah lokasi yang mengandung atau diduga mengandung benda cagar budaya termasuk lingkungannya yang diperlukan bagi pengamanannya.
}

tahun 1931, tepatnya dibuat pada masa pemerintahan Kuwu Haji Marsiti (1915), Kuwu Haji Daklan (1916), Kuwu Haji Akmad (1917), Kuwu Haji Kusen (1920), dan Kuwu Haji Saleh (1931). Haji Kusen termasuk paling lama menjabat sebagai kepala Dusun Srengseng, sekitar 11 tahun, sebagaimana terlihat dalam arsip-arsip lain yang ditulis pada rentang masa itu.

Jika diperhatikan, betapa seorang haji memiliki kepercayaan lebih besar di hati masyarakat dibandingkan dengan meraka yang belum pernah menunaikannya. Seorang haji seakan menjadi syarat mutlak dan lebih layak menempati jabatan kuwu. Sebelum tahun 1915, di desa Srengseng, jabatan kuwu juga diisi oleh seorang haji, yaitu Haji Kadam (disebutkan dalam surat tertanggal 09 Maret 1917). ${ }^{7}$

Bila arsip-arsip dari Desa Srengseng saya telusuri lebih jauh, bisa saja jumlahnya lebih banyak lagi. Terlebih lagi, Srengseng tergolong desa tua yang memiliki perjalanan sejarah cukup panjang, yaitu sejak era Sunan Gunung Jati, yang tidak menutup kemungkinan menyimpan banyak benda cagar budaya selain naskah. Masyarakat meyakini bahwa Ki Gede Srengseng sebagai pendiri desa itu, sekitar abad ke-15.

7 Bahwa haji lebih dari sekedar menyempurnakan rukun Islam, tetapi sekaligus sebagai alat legitimasi politik, terlihat sejak masa awal perkembangan Islam. Hal ini tampak pada kisah perjalanan Walangsungsang beserta adiknya, Rarasantang, ke tanah suci pada abad ke-15. Sepulang dari sana, Pangeran Walangsungsang menjadi kuwu (yang lebih dikenal dengan Kuwu Sangkan atau Mbah Kuwu), yang dengannya mendapatkan karpet merah dari masyarakat muslim pesisir, terlebih lagi Walangsungsang adalah putra mahkota Pajajaran. Demikian pula Banten, dalam Sajarah Banten yang ditulis pada abad ke-17, status haji memiliki fungsi sebagai alat legitimasi politik (Bruinessen, 1995: 42). 


\section{Surat Akta Jual Beli Sawah \\ a. Tentang Surat}

Naskah akta jual beli sawah ditulis dengan aksara Jawa, menggunakan bahasa Jawa. Alas tulis menggunakan kertas bergaris. Tulisan sangat rapi sehingga teks mudah dibaca. Pola penulisannya mengikuti garis. Teks beraksara latin hanya pada penulisan angka (nomor dan penanggalan) serta nama seseorang (sekretaris I), selebihnya tertulis dengan aksara Jawa. Tinta yang digunakan berwarna hitam. Surat ini hanya satu lembar; teks tertulis hanya pada satu sisi halaman. Jumlah baris 22. Beberapa baris terakhir ditulis menjorok ke tepi kanan.

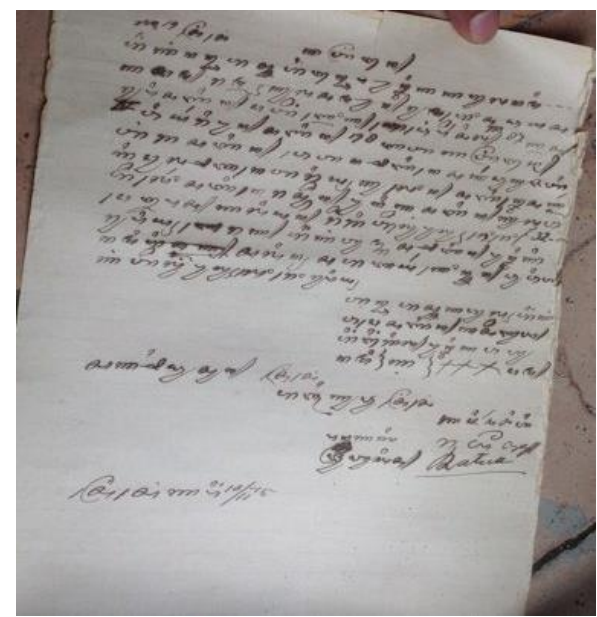

Gambar 2. Surat Jual Beli Sawah tahun 1915

Sumber: Nurhata, 2017.

Meskipun kondisi surat sudah lapuk dan kusam, akan tetapi keseluruhan teks masih terbaca. Surat-surat lainnya pun, yang tersimpan dalam satu koleksi, kondisinya seperti itu. Penyebab umum yang melatarainya karena pemilik naskah tidak memahami bagaiamana semestinya merawat atau memperlakukan naskah. Pemilik juga kurang berhati-hati ketika membukakan surat-surat yang tergulung dalam tabung kaleng. Akibatnya, tepi halaman banyak yang rusak, tersobek menjadi serpihan kecil dan berjatuhan ke tanah.

Bila dibandingkan dengan surat kepemilikan tanah di Priangan yang dibuat pada awal abad ke-20, surat jual beli tanah asal Desa Srengseng memiliki kemiripan, bahkan keduanya sama-sama menggunakan aksara Jawa. Kandungan isinya sama-sama menjelaskan luas tanah, batas tanah, harga sawah, yang menggadaikan (atau yang menjual), nama pembeli, saksi-saksi, dan titimangsa. Hanya saja bahasa yang digunakan telah disesuaikan. Surat dari Indramayu ditulis dengan bahasa Jawa, sedangkan surat dari Priangan ditulis dengan bahasa Sunda (Ruhaliah, 2010: 57).

\section{Alih Aksara}

Format alih aksara atau transliterasi pada surat jual beli sawah di bawah ini tetap mempertahankan struktur atau pola, agar memperoleh gambaran yang sedekat mungkin dengan yang aslinya. Berkenaan dengan konsonan $h$ pada awal kata, juga tetap dipertahankan, seperti kata hingkang, hing, dan habdi.

\section{No. 19 Sréngséng/}

\section{Katrangan/}

Hingkang nandha hasta hing ngandhap punika kahula namil Kadam Ramlah. Kula sampun rumahos gadha yasal rupi sabin dateng Blok Bédhéng, persil 87, klas/ IV. Wiyaripun sabin 198 bata. Katrangan/ tangga sabin, wétan sabiné Sakar Dukujati,/ kidul sabiné $e^{8}$ Tariyah, kulon sabiné Sakar,/ helor sabiné Rasden. Punika sabin kula wa/dé lepas, kaliyan regi telung puluh roro f32/ rupiyah pérak. Hingkang tumbas sabin puniki/ nami Salinah, saha bayar kontan dhuwit/ kang telung puluh loro rupiyah.

Tandha hasta kahulah hingkang/wadé sabin

kasebut/ hing ngigil punika wahu/nami Kadam.

Saksi Dhusun Sréngséng

Habdi Kuwu Sréngséng

Kaji Marsiti

\footnotetext{
${ }^{8}$ Dalam naskah tertulis sabané, seharusnya sabiné.
} 
Panca Kaki, Rayem(?)

Jru Tulis, Ratna

Sréngséng kaping 10/11/-15

Keterangan:

é $\quad$ taling

e pepet

/ ganti baris

? kata sukar dibaca

\section{Terjemahan}

Terjemahan surat di bawah ini, dari segi strukturnya, mengikuti alih aksara atau sumber aslinya. Berikut di bawah ini terjemahannya.

Nomor 19 Srengseng

Keterangan

Yang bertanda tangan di bawah ini, saya (kami) bernama Kadam [dan] Ramlah. Saya merasa memiliki sebidang tanah berupa sawah di Blok Bedeng, persil [nomor] 87, kelas IV. Luas sawah 198 bata. Keterangan tetangga sawah: timur sawah milik Sakar, Duku[h]jati; selatan sawah milik Tariyah; barat sawah milik Sakar; utara sawah milik Rasden. Sawah ini saya jual lepas dengan harga f32, tiga puluh dua rupiah perak. Yang membeli sawah bernama Salinah. Dibayar tunai uang yang tiga puluh dua rupiah.

Tanda tangan saya yang menjual sawah tersebut di atas bernama Kadam.

Saksi Dusun Srengseng

Abdi Kuwu Srengseng

Haji Marsiti

Srengseng 10 November [19]15

Pancakaki, Rayem

Juru Tulis, Ratna

Keterangan:

(...) keterangan tambahan

[...] tambahan kata atau huruf
4. Isi Surat Keterangan Jual Beli Sawah

Ada tiga unsur utama dalam surat akta jual beli sawah: struktur, isi, dan konteks. Keseluruhan surat yang diperoleh dari Desa Srengseng, termasuk yang berasal dari Priangan, juga mengandung tiga unsur itu. Adapun garis besar isi surat adalah penjualan sebidang tanah sawah. Tepatnya, pada tanggal 10 November 1915, sawah milik Bapak Kadam dan Ibu Ramlah seluas 198 bata, yang berlokasi di Blok Bedeng, dijual kepada Bapak Salinah dengan harga 32 rupiah. Adapun sebagai saksinya adalah Pancakaki yang bernama Rayem dan Juru Tulis I yang bernama Ratna.

Beberapa unsur yang akan diuraikan berkenaan dengan isi surat yaitu luas sawah, batas sawah (sebelah barat, timur, utara, dan selatan), harga sawah, nama penjual, nama pembeli, saksi-saksi, dan waktu transaksi (penanggalan). Di samping itu juga akan dijelaskan masalah tanda tangan cap jempol dan stempel, meskipun tidak termuat di dalam surat yang menjadi obyek penelitian ini, karena kedua unsur itu juga sangat penting.

\section{a. Luas dan Batas Sawah}

Ukuran luas menggunakan istilah (ukuran) lama, yang biasa digunakan oleh orang-orang terdahulu, yaitu bata. Sampai saat ini pun, sebagian orang-orang desa di Indramayu, masih menggunakan istilah bata ketika mengukur sebidang tanah. Satu bata sama dengan $14 \mathrm{~m}^{2}$. Pendapat lain, satu bata sama dengan $14,25 \mathrm{~m}^{2}$, hanya selisih sedikit. Di atas bata yaitu patok dan bau. Satu patok sama dengan setengah bau, sekitar $3500 \mathrm{~m}^{2}$. KBBI (2008: 1030) mengartikan satu patok sekitar $2300 \mathrm{~m}^{2}$. Sementara itu, satu bau sama dengan (sekitar) $7000 \mathrm{~m}^{2}$. Dengan demikian, 198 bata sama dengan $2772 \mathrm{~m}^{2}$.

Di dalam surat terdapat keterangan bagian sisi atau tetangga sawah. Letak sawah yang dijual berlokasi agak menjorok ke dalam, tidak berbatasan dengan sungai atau pekarangan. 
a. Sebelah timur berbatasan dengan sawah milik Sakar (dari Dukuhjati, Indramayu);

b. Sebelah selatan berbatasan dengan sawah milik Tariyah;

c. Sebelah barat berbatasan dengan sawah milik Sakar;

d. Sebelah utara berbatasan dengan sawah milik Rasden.

Keterangan tersebut, secara substansial tidak jauh berbeda dari surat pernyataan penguasaan fisik bidang tanah atau surat pernyataan kepemilikan tanah pada masa kini. Ini bisa dibandingkan dengan surat akta tanah yang dibuat pada tahun 1991, milik Ibu Farikhah, Indramyu. Hanya saja, surat penguasaan tanah yang dibuat belakangan, dilengkapi dengan denah lokasi. Selain itu juga memuat tanda tangan penjual, pembeli, saksi-saksi, termasuk kepala desa dan camat.

Pemberian batas biasanya diberi penanda tonggak berupa kayu atau benda keras lainnya, yang diletakkan di empat sudut, membentuk garis persegi. Penanda itu sebagai pengingat batas luas tanah, baik oleh pemilik sawah sendiri maupun tetangga sebelahnya. Ketika tanah dijual setengahnya, atau dibagi menjadi dua, maka diberi tonggak lagi, dan seterusnya, misalnya karena pembagian waris.

\begin{tabular}{|l|l|l|}
\cline { 2 - 3 } \multicolumn{1}{c|}{} & $\begin{array}{l}\text { Selatan, } \\
\text { Sawah milik } \\
\text { Tariyah }\end{array}$ & \\
\hline $\begin{array}{l}\text { Timur, } \\
\text { Sawah milik } \\
\text { Sakar }\end{array}$ & $\begin{array}{l}\text { Sawah yang } \\
\text { djual, luas } \\
198 \text { bata } \\
\text { atau 2772 } \\
\mathrm{m}^{2}\end{array}$ & $\begin{array}{l}\text { Barat, } \\
\text { Sawah milik } \\
\text { Sakar }\end{array}$ \\
\hline & & \\
& $\begin{array}{l}\text { Utara, } \\
\text { Sawah milik } \\
\text { Rasden }\end{array}$ & \\
\cline { 2 - 3 } &
\end{tabular}

Gambar 3. Ilustrasi batas sawah

\section{b. Jenis dan Kelas}

Sawah yang terletak di Blok Bedeng adalah sawah bernomor persil 87, kelas IV. Dalam kamus Bausastra Jawa (Widada dkk., 2001), tanah persil adalah tanah negara yang disewakan oleh seseorang selama 75 tahun. Tanah persil juga berarti suatu tanah yang dipakai untuk dijadikan sebagai ladang perkebunan, pertanian, atau untuk perumahan. Konteks jual beli sawah yang dimaksud dalam surat tersebut merujuk pada definisi yang kedua. Dengan kalimat lain, sebagai tanah persawahan yang dijual kepada pihak lain.

Sementara itu, dilihat dari jenis kelasnya, tanah tersebut termasuk lahan produktif dan subur. Pengelolaan yang baik terhadap tanah kelas IV dapat memperoleh hasil melimpah sesuai dengan tujuannya, misalnya untuk penanaman tanaman pertanian, tanaman musiman (biasanya sekali dalam setahun), rumput untuk pakan ternak, padang rumput, atau hutan.

\section{c. Harga Sawah}

Harga sawah seluas 198 bata atau $2772 \mathrm{~m}^{2}$ adalah 32 rupiah perak. Nilai itu terbilang besar pada masanya. Bapak Salinah membelinya secara tunai. Kedua nilai uang disebutkan: rupiah dan perak. Dalam percakapan sehari-hari, terutama masyarakat Cirebon dan Indramayu, istilah perak kerap dipakai untuk menunjukkan bahwa nominal uang yang dimaksud sangat kecil, misalnya séwu pérak "1000 rupiah".

\section{d. Nama Penjual}

Disebutkan nama orang yang menjual sawah, yaitu Kadam Ramlah, pemilik sah dari sawah yang dijual. Tampaknya mereka adalah pasangan suami-istri: Bapak Kadam dan Ibu Ramlah. Tentang asal si penjual tidak disebutkan, hanya terdapat keterangan letak sawah dan batas sawah. Menurut surat tanah yang dibuat pada tanggal 3 Maret 1917, Bapak Kadam adalah seorang mantan kuwu. Besar kemungkinan ia berasal dari Desa 
Srengseng juga. Ia juga memiliki sawah di Blok Glagarjuna Srengseng, berbatasan dengan sawah milik Bapak Mursid. ${ }^{9}$

Banyak faktor yang melatari mengapa Bapak Kadam dan Ibu Ramlah menjual sawahnya, ditengarai karena masalah kebutuhan ekonomi. Hal ini dipertegas dengan adanya sebuah laporan seorang Wakil Inspektur Urusan Agraria (1918-1925), J.W. Meijer Ranneft sewaktu melakukan perjalanan dinas ke wilayah utara Cirebon serta penelitian Armando (2010) di Indramayu bagian berat (18851935).

Pada surat tersebut, hanya disebutkan nama Bapak Kadam: Tandha hasta kahulah hingkang wadé sabin kasebut hing ngigil punika wahu nami Kadam "Tanda tangan saya yang menjual sawah tersebut di atas bernama Kadam". Nama Ibu Ramlah tidak tertera. Tanda tangan penjual juga tidak ada, hanya ada tanda yang menyerupai huruf "XXX" yang mungkin maksudnya dikosongkan. Bahkan tanda tangan kuwu, saksi, dan stempel pun tidak tertera. Belum dapat dipastikan, apakah surat semacam itu pada masanya dianggap lazim dan memiliki kekuatan hukum atau memang masih dalam proses (belum selesai).

\section{e. Nama Pembeli}

Pada mulanya saya menduga, pembeli sawah yang bernama Salinah adalah perempuan, tetapi ternyata laki-laki. Ini dinyatakan dalam surat lain yang ditulis sesudahnya. Menurut pemilik naskah pun seperti itu, bahwa Salinah adalah seorang laki-laki yang memiliki banyak sawah. Boleh dibilang pemerolehan tanah didapat dengan cara membeli. Berikut di bawah ini tanggal pembeliannya:

1. Tanggal 11 September 1918, Bapak Salinah membeli sawah dari Ibu

\footnotetext{
${ }^{9}$ Keterangan tetangga sawah milik Kasni yang djual ke Bapak Mursid pada tanggal 3 Maret 1917: timur, sawahnya Haji Hartiyah; selatan, tetangga Ibu Masijem; barat, Kaji Kadam, mantan kuwu; utara, tetangga salon.
}

Redisan seluas 342 bata dengah harga 80 rupiah.

2. Tanggal 4 Agustus 1920, Bapak Salinah membeli sawah milik Ibu Wader seluas 282 bata dengan harga 80 rupiah.

3. Tanggal 7 November 1923, Bapak Salinah membeli sawah seluas 198 bata milik Bapak Kaswi dan Ibu Murtala dengan harga 50 rupiah.

4. Tanggal 31 Oktober 1924, Bapak Salinah membeli sawah seluas 260 $r u$ atau sekitar setengah bau lebih $(500 r u=1$ bau $)$ milik Ibu Salmi seharga 210 rupiah.

5. Tanggal 3 Agustus 1931, Bapak Salinah membeli sawah milik Ibu Sanip seluas 262 bata dengan harga 65 rupiah.

Jadi, total luas sawah yang dimiliki Bapak Salinah 2600 bata atau sekitar 3.66 hektar. ${ }^{10}$ Jumlah ini belum termasuk tanah pekarangan, yang jika diakumulasikan lebih luas lagi ukurannya.

Sejumlah surat akta jual beli tanah milik Bapak Salinah seakan menegaskan bahwa ia adalah seorang tuan tanah. Sawahnya tersebar luas di Dusun Srengseng. Hampir setiap dua tahun ia membeli sawah yang berada di area desa itu. Informasi ini senada dengan yang disampaikan oleh pemilik surat, Mas Johan, bahwa Bapak Salinah memang betul adalah tuan tanah. ${ }^{11}$ Kepemilikan tanah perorangan dalam jumlah besar ini adalah salah satu dampak dari Undangundang Agraria (Agrarische Wet) sebagaimana telah disebutkan di atas.

\section{f. Tanda Tangan}

Di dalam surat yang dialihkasarakan sebagaimana diuraikan di atas, tidak memuat tanda tangan cap jempol dan

\footnotetext{
${ }^{10}$ Ini data sementara. Dari dua gulungan yang dimasukkan dalam dua kaleng, hanya sebagian surat yang saya baca, masih banyak surat yang belum dibaca. Jika diakumualasikan jumlahnya lebih besar lagi, bisa mencapai dua kali lipat.

${ }^{11}$ Wawancara dengan pemilik arsip, Mas Johan (40).
} 
stempel. Akan tetapi, merujuk pada beberapa surat yang dibuat setelahnya, terdapat tanda tangan penjual, berupa cap jempol, seperti surat yang dibuat pada 4 Agustus 1920, perihal penjualan sawah milik Ibu Wader kepada Bapak Salinah, seluas 282 bata, dengan harga 80 rupiah. Surat-surat lainnya, tentang pembelian sebidang sawah, yang memuat tanda tangan, yaitu tertanggal 4 Oktober 1923; 7 November 1923; 31 Oktober 1924; 3 Agustus 1931.

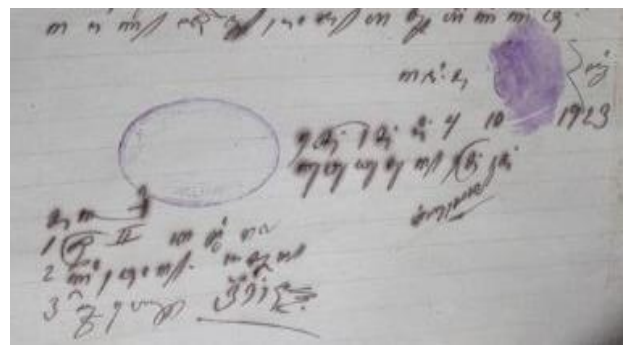

Gambar 4. Cap Jempol dan Stempel Sumber: Nurhata, 2017.

\section{g. Stempel}

Surat berstempel sebetulnya hanya ada dua: tertanggal 3 September 1917 dan tertanggal 4 Oktober 1923. Dalam stempel tertulis serangkaian huruf melingkar, berupa huruf kapital aksara latin: "SRENGSENG NO. 19. DIST. KARANGAMPEL". Pada bagian tengah lingkaran terdapat gambar mahkota. Di bagian bawah mahkota terdapat gambar dua ekor singa dengan posisi berdiri, tetapi tidak begitu jelas. Stempel dengan gambar semacam itu biasa dipakai untuk urusan yang berkaitan dengan administrai pemerintah Hindia Belanda pada awal abad ke-20.

Ini menginformasikan kedudukan Dusun Srengseng kala itu sebagai wilayah yang berada di bawah Distrik Karangampel, melalui Onderdistrik Krangkeng. Berbeda dari hierarki pemerintahan saat ini, Karangampel dan Krangkeng memiliki kedudukan sejajar, keduanya sebagai kecamatan yang berada di bawah Pemerintahan Kabupaten Indramayu.

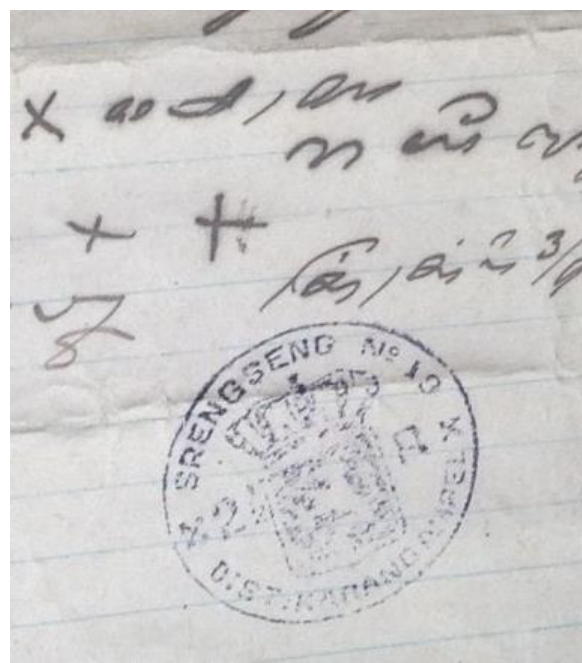

Gambar 5. Stempel

Sumber: Nurhata, 2017.

\section{h. Saksi-saksi}

Orang-orang yang terlibat dalam penjualan sawah adalah Kuwu Dusun Srengseng Haji Marsiti, sebagai pihak yang mengetahui. Di bawahnya disebutkan dua orang saksi, yakni Pancakaki yang bernama Rayem dan Juru Tulis yang bernama Ratna (Juru Tulis I). Biasanya, juru tulis yang bertugas membuat surat penting seperti akta jual beli. Keterlibatan pihak desa sangat penting, untuk mengantisipasi timbulnya perselisihan di antara kedua belah pihak.

Ratna termasuk orang yang berpengalaman dalam urusan administrasi desa. Pada masa kuwu H. Marsiti, Ratna menduduki jabatan juru tulis atau sekretaris I, nama sekretaris II tidak disebutkan. Masa kuwu H. Daklan, Ratna juga menjabat sekretaris I, bersama Mustarah sebagai sekretaris II. Masa Kuwu H. Kusen, Ratna masih menjadi sebagai sekretaris I, sedangkan yang menjadi sekretaris II adalah Klawud. Namun, periode pemerintahan Kuwu H. Kusen, jabatan sekreteris I dan II diganti: sekretaris I diganti menjadi $\mathrm{H}$. Yahya sementara sekreteris II diganti menjadi Kasmirah.

Adapun nama-nama jabatan yang ada di Dusun Srengseng, menurut 
keseluruhan surat (yang terhimpun dalam satu koleksi), sebagai berikut:

1. Kuwu: kepala desa;

2. Juru tulis: sekretaris desa. Dalam naskah biasanya ditulis (disingkat) jru;

3. Keliwon: Kedudukannya di bawah lurah desa. Kamus KBBI (2008: 657), mengartikan keliwon sebagai pamong desa yang kedudukannya berada di bawah kuwu;

4. Malang: perangkat desa yang bertugas menjamin keamanan desa, seperti polisi desa. Kedudukannya di atas lurah desa;

5. Raksabumi: perangkat desa yang bertugas mengawasi masalah pengairan dalam satu desa;

6. Lurah: di sini, yang disebut lurah adalah kepala dusun, bukan kepala desa atau kuwu. Lurah desa juga disebut dengan penggedhé desa. Di Indramayu, kira-kira satu lurah membawahi tiga atau empat RW (Rukun Warga);

7. Kebayan: perangkat desa yang bertugas menjadi suruhan pamong desa. Dalam KBBI (2008: 642), kebayan berarti pamong desa yang bekerja menyampaikan perintah sekaligus menjaga keamanan di desa;

8. Lebe: perangkat desa yang biasanya bertugas menikahkan seseorang dengan pasangannya dan mengurusi jenazah;

9. Pancakaki: orang yang dituakan (sesepuh desa)

10. Bekel: kepala yang membawahi beberapa blok. Kira-kira, tiga blok dibawah satu bekel. Jadi, satu desa terdiri atas beberapa bekel.

\section{PENUTUP}

Berdasarkan jenisnya, naskah surat akta jual beli sawah koleksi Mas Johan, Srengseng Indramayu, termasuk surat penting. Asal surat, warisan dari buyutnya, Bapak Salinah. Bapak Salinah adalah pemilik pertama sekaligus sebagai pembeli sawah. Ia mengamanatkan seluruh surat berharga itu kepada anak cucunya, supaya dirawat dengan baik.

Naskah surat akta jual beli sawah yang dibuat pada tahun 1915 adalah bukti sah kepemilikan atas sebidang sawah. Di dalamnya menyatakan bahwa sawah berukuran luas 198 bata $\left(2772 \mathrm{~m}^{2}\right)$, milik Bapak Kadam dan Ibu Ramlah, dibeli oleh Bapak Salinah dengan harga 32 rupiah, dibayar tunai. Dilihat dari jenis dan kelas tanahnya menunjukkan, sawah tersebut tergolong lahan subur dan produktif.

Adapun jumlah keseluruhan tanah sawah yang dimiliki Bapak Salinah, hingga tahun 1931, seluas 2600 bata atau sekitar 3,66 hektar. Semua sawah dibeli pada rentang waktu yang berbeda. Ia membelinya secara bertahap, selama 16 tahun (1915-1931). Lokasi antara satu sawah dan sawah lain berjauhan, tetapi masih dalam satu desa.

\section{UCAPAN TERIMA KASIH}

Penelitian ini selesai disusun dalam wujud artikel, karena ketersediaan arsip koleksi Mas Johan. Oleh karena itu saya mengucapkan terima kasih kepada Mas Johan yang telah mempersilahkan seluruh arsip pribadinya untuk saya jadikan bahan kajian penelitian. Terima kasih pula saya sampaikan kepada Rahmatullah, yang telah meluangkan waktu dan tenaganya, mengantarkan saya ke rumah pemilik arsip.

\section{DAFTAR SUMBER}

\section{Naskah atau Arsip}

Akta Tanah, dibuat pada tahun 1991, milik Ibu Farikhah (48 tahun).

Naskah Sedjarah Kuntjit, ditulis pada tahun 1918, koleksi Ki Masta (alm.).

Naskah Babad Darmayu, tt. koleksi Dalang Ahmadi.

Naskah Akta Surat Jual Beli Sawah, dibuat tahun 1915, koleksi Mas Johan (40 tahun). 
Naskah Akta Surat Jual Beli Sawah, dibuat tahun 1916, koleksi Mas Johan (40 tahun).

Naskah AktaSurat Jual Beli Sawah, dibuat tahun 1917, koleksi Mas Johan (40 tahun).

Naskah AktaSurat Jual Beli Sawah, dibuat tahun 1920, koleksi Mas Johan (40 tahun).

Naskah AktaSurat Jual Beli Sawah, dibuat tahun 1923, koleksi Mas Johan (40 tahun).

Naskah AktaSurat Jual Beli Sawah, dibuat tahun 192, koleksi Mas Johan (40 tahun).

Naskah Akta Surat Jual Beli Sawah, dibuat tahun 1931, koleksi Mas Johan (40 tahun).

Naskah Akta Surat pernyataaan penguasaan fisik bidang tanah, 1991, arsip pribadi (40 tahun).

\section{Jurnal dan Laporan Penelitian}

Christmoy, Tommy dan Nurhata. 2016.

"Kearifan Lokal dalam Naskah-naskah Pesisir Indramayu: Pengembangan Budaya Pesisir melalui Knowledge Management System". DRPM. UI.

Fernando, M.R. "The Worst of Both Worlds: Commercial Rice Production in West Indramayu, 1885-1935" dalam of Southeast Asian Studies, Vol. 41 / Issue 03 / October 2010, pp 421 - 448.

Krihanta. "Akreditasi Lembaga Kearsipan Provinsi dalam Rangka Meningkatkan Layanan kepada Masyarakat" dalam ANRI Jurnal Kearsipan Vol. 3 No.1. Desember Tahun 2008.

Magetsari, Nurhadi. "Organisasi dan Layanan Kearsipan” dalam ANRI Jurnal Kearsipan Vol. 3 No.1. Desember Tahun 2008.

Muhsin Z, Mumuh. 2011. "Struktur Sosial, Politi, dan Pemilikan Tanah di Priangan Abad ke-19" dalam Patanjala Vol. 3 No. 3. September 2011.

Mulyadi, Sri Wulan Rujiati. 1994.

"Kodikologi Melayu di Indonesia", dalam Lembaran Sastra edisi khusus.
21. Depok: Fakultas Sastra Universitas Indonesia.

Purwanti, Sri. “Akibat Hukum dari Pembuatan Akta Jual Beli Tanah yang tidak Sesuai dengan Tata Cara Pembuatan Akta PPAT" dalam Repertorium Vol. 3 No. 2. Juli-Desember 2016.

Ruhaliah. "Jejak Penjajahan pada Naskah Sunda: Studi Kasus pada Surat Tanah" dalam Jumantara Vol. 1 No. 1. Tahun 2010.

Winarso, Bambang. "Dinamika Pola Penguasaan Lahan Sawah di Wilayah Pedesaan di Indonesia" dalam Jurnal Penelitian Pertanian Terapan Vol. 12 No. 3. Tahun 2012.

\section{Buku}

Abdullah, Taufik. 2010. Sejarah Lokal di Indonesia. Yogyakarta: UGM Press.

Baried, Siti Baroroh dkk. 1985. Pengantar Teori Filologi. Pusat Pembinaan dan Pengembangan Bahasa, Departemen Pendidikan dan Kebudayaan, Jakarta.

Christmoy, Tommy dan Nurhata. 2016. Katalog Naskah Indramayu. Jakarta: WWS.

Departemen Pendidikan Nasional. 2008. Kamus Besar Bahasa Indonesia. Edisi IV. Jakarta: Gramedia Pustaka Utama

Farid, Hilmar. 2017. "Prolog: Menuju Sejarah/ Geografi Agraria". dalam Sejarah/Geografi Agraria Indonesia. Sleman: STPN Press.

Hornby, A. S. 2000. Oxford Advanced Learner's Dictionary. Oxford: Oxford University Press.

Priyadi, Sugeng. 2012. Sejarah Lokal: Konsep, Metode, dan Tantangannya. Yogyakarta: Ombak.

Saputra, Karsono, H. 2008. Pengantar Filologi Jawa. Jakarta: WWS.

Suhendar, Endang. 1995. Ketimpangan Penguasaan Tanah di Jawa Barat. Akatiga: Bandung. 
Van Bruinessen, Martin. 1995.

Kitab Kuning: Pesantren dan Tarekat.

Bandung: Mizan.

Van Anrooij, Francien. 2014.

De Koloniale Staat (Negara Kolonial)

1854-1942. Panduan Archief van het

Ministerie van Kolonien (Arsip

Kementrian Urusan Tanah Jajahan

Kepulauan Nusantara. Penerjemah

Nurhayu W. Santoso dan Susi

Moeimam. Leiden.

Widada, dkk., 2001.

Kamus Basa Jawa (Bausastra Jawa). Yogyakarta: Kanisius.

Zoetmulder, P.J. 1983.

Kalangwan: Sastra Jawa Kuno Selayang Pandang. Jakarta: Jambatan.

\section{Undang-undang dan Peraturan}

Pemerintah

Undang-undang Republik Indonesia, Nomor 5 Tahun 1992, tentang Benda Cagar Budaya.

Peraturan Kepala Arsip Nasional Republik Indonesia Nomor 22 Tahun 2011

tentang Pedoman Penyelenggaraan Sistem Informasi Kearsipan Nasional (SIKN) dan Jaringan Informasi Kearsipan Nasional (JIKN).

Peraturan Pemerintah Republik Indonesia Nomor 24 Tahun 1997, tentang Pendaftaran Tanah, Presiden Republik Indonesia.

\section{Informan}

Mas Johan (40 tahun). 2015.

Desa Srengseng, Kec. Krangkeng, Kab. Indramayu. Wawancara, Indramayu 22 Januari 2015. 